\title{
THE PROPOSED INSTITUTE FOR MICRO-MANUFACTURING LOUISIANA TECH UNIVERSITY
}

\author{
PREPARED BY \\ U.S. DEPARTMENT OF ENERGY
}

JULY, 1994

\section{DISCLAIMER}

This report was prepared as an account of work sponsored by an agency of the United States Government. Neither the United States Government nor any agency thereof, nor any of their employees, makes any warranty, express or implied, or assumes any legal liability or responsibility for the accuracy, completeness, or usefulness of any information, apparatus, product, or process disclosed, or represents that its use would not infringe privately owned rights. Reference herein to any specific commercial product, process, or service by trade name, trademark, manufacturer, or otherwise does not necessarily constitute or imply its endorsement, recommendation, or favoring by the United States Government or any agency thereof. The views and opinions of authors expressed herein do not necessarily state or reflect those of the United States Government or any agency thereof. 


\section{DISCLAIMER}

Portions of this document may be illegible in electronic image products. Images are produced from the best available original document. 
1.0 DOCUMENT SUMMARY

2.0 PURPOSE AND NEED

3.0 DESCRIPTION OF ALTERNATIVES, INCLUDING THE PROPOSED ACTION . . . . . . . 2

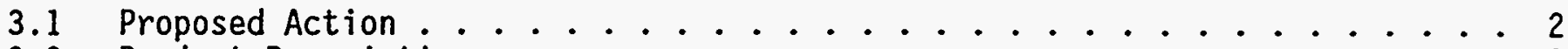

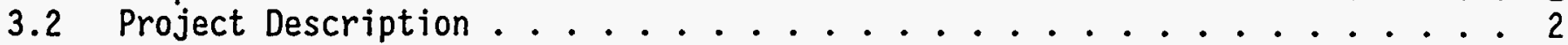

3.3 No Action Atternative ................... 7

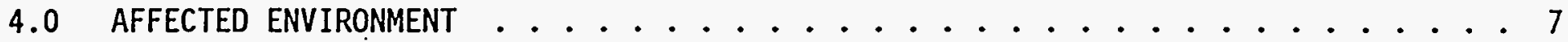

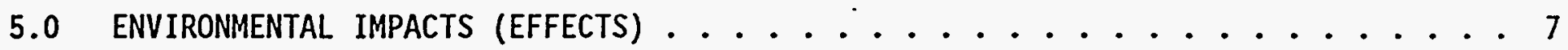

5.1 Construction of the Proposed Ruston Campus Research and Development

5.2 Operation of the Proposed Ruston Campus Research and Development

5.3 Installation and Operation of the Proposed Beamline at the Center for Advanced Microstructures and Devices . . . . . . . . . . . 14

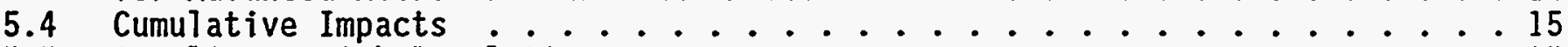

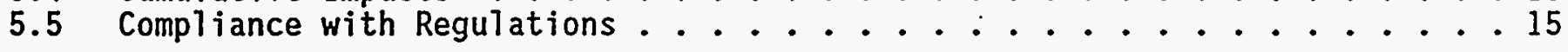

6.0 RELATIONSHIP OF THE PROPOSED ACTION TO OTHER ACTIONS AND ACTIONS BEING CONSIDERED UNDER OTHER NATIONAL ENVIRONMENTAL POLICY ACT REVIEHS . . . . . . . . . 15

7.0 RELATIONSHIP OF PROPOSED ACTION TO ANY APPLICABLE FEDERAL, STATE, REGIONAL OR LOCAL LAND USE PLANS AND POLICIES LIKELY TO BE AFFECTED . . . . . . . . . 15

8.0 LISTING OF AGENCIES AND PERSONS CONSULTED . . . . . . . . . . . . 16

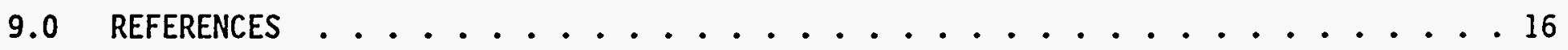

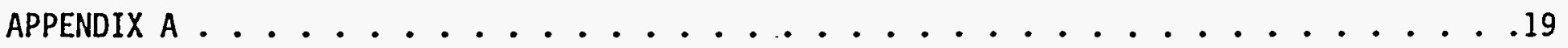

Figure

\section{LIST OF FIGURES}

Figure 1 City Locations of the Three Components of the Institute for

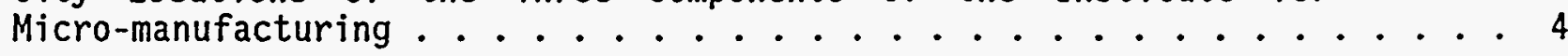

Figure 2 Proposed Ruston Campus Research and Development Facility ....... 5

Figure 3 Proposed Ruston Campus Research and Development Facility ....... 6 


\subsection{DOCUMENT SUMMARY}

The Department of Energy (DOE) proposes to authorize Louisiana Tech University (LTU) in Ruston, Louisiana, to proceed with the detailed design, construction, and equipping of two components of the Institute for Micro-manufacturing (Institute).

The Institute would have three major components all of which are covered by the grant. However, one component, a Technology Transfer Center, is not being authorized at this time. Although contemplated for construction sometime in the future, planning for this facility is not far enough along to allow for a meaningful evaluation of environmental impacts. A separate National Environmental Policy Act (NEPA) review would be performed by DOE prior to authorization of that component of the proposed Institute.

The primary component proposed to be authorized would be a new Ruston campus Research and Development (R\&D) facility on the LTU campus in Ruston devoted to the design, development, testing, assembly, and production of micron and submicron structures and devices. Construction would entail removal of selected trees and temporary environmental impacts typical of small building erection, including some temporary and intermittent daytime nuisance to nearby residential units. The proposed site is vacant and it has no unique historical, cultural, archeological, or natural features. It would not impact of wetland, floodplain, coastal zone, nor is it prime farmland. Operation of the proposed facility would not involve use of radioactive or biological materials, but it would involve use of a number of hazardous materials including toxic, flammable, and corrosive chemical laböratory solvents and reagents. Some of these hazardous materials would be vented to the atmosphere. None of the hazardous materials have exposure limits specified by the National Emission Standards for Hazardous Air Pollutants. Analysis shows that potential exposure of the public and workers due to atmospheric venting would typically. be several orders of magnitude less than Threshold Limit Values listed in Sax's Dangerous Properties of Industrial Materials. Storage, handling, laboratory use, and disposal of hazardous materials/wastes that would be used at this proposed R\&D facility will be managed by the University's Environmental Safety Department in compliance with state and federal regulations.

The second proposed component would be an additional beamline at the Center for Advanced Microstructures and Devices (CAMD) at Louisiana State University (LSU) in Baton Rouge, Louisiana. This proposed component would enable LTU to perform research associated with the $x$-ray lithography micro-machining capability at CAMD. The only construction associated with creation of a new dedicated beamline off the electron storage ring at CAMD would be equipment assembly at the beam port to direct the beam to designated target areas. This activity would take place within the existing building at LSU in Baton Rouge. Radiation would be present during the operation of the beamline to designated target areas at the CAMD Facility. The estimated cumulative dose for a worker at the proposed facility would be 0.362 roentgen equivalent man (a unit of dose) per year (rem/year), which is far below the DOE annual cumulative dose guideline of $5.0 \mathrm{rem} / \mathrm{year}$.

The DOE alternative to the proposed action is no action (i.e., no funding). This alternative would result in a delay in project implementation by LTU, depending upon availability of alternative funding sources. However, inasmuch as LTU has already committed itself to the first two proposed components, the environmental impacts of the no action alternative would be consistent with those of the proposed action (Figure 1).

The proposed CAMD component is related to a DOE NEPA review performed for construction of the CAMD in 1990. The proposed actions would conform with all applicable federal, state, and local land use plans and policies. 


\subsection{PURPOSE AND NEED}

Congress has provided funds to DOE to assist in the construction of the Institute at LTU. DOE's purpose is to carry out this congressional intent (described below) and to contribute to its own mission by supporting research programs the proposed Institute.

The U.S. microelectronics industry (which is involved with the production of integrated. circuits and computer chips) is widely perceived as losing ground to Japan and Europe, especially in the micro-manufacturing arena. (Micro-manufacturing is a set of processes for the creation of structures, devices, or systems which feature sizes typical7y on the order of micrometers). To correct this imbalance, LTU proposes to establish a vigorous program, based on the lines pursued in Japan and Europe, jointly funded by industry and government. LTU would establish the proposed Institute to incorporate basic research and advanced training in material sciences to meet the long-term needs of the U.S. microelectronics industry, and to enhance U.S. microelectronics industrial competitiveness in the international arena. The integration of microelectronics and micro-mechanical devices is the focus of Micro-Manufacturing and will enhance the competitiveness of many of other industries in the United States through the enhancement of existing products and the creation of new products.

\subsection{DESCRIPTION OF ALTERNATIVES INCLUDING THE PROPOSED ACTION}

\subsection{Proposed Action}

The DOE proposes to authorize LTU to proceed with the detailed design and construction of the proposed Ruston campus R\&D facility for the Institute and a newly proposed beamline for micro-machining applications at the CAMD Facility at Louisiana State University. A third component under the grant is not being authorized at this time. Prior to authorization, DOE would complete a NEPA review of that facility, a Technology Transfer Center contemplated by LTU for sometime in the future (Figure 1).

Senate Committee Report 101-378 (Reference (Ref.) 1), the Energy and Water Development Appropriations Act, 1991 (Pub7ic Law 101-515) for the proposed facility approved $\$ 750,000$ of the recommended appropriation (reduced to $\$ 745,650$ by the Gramm-Rudman Deficit Reduction Act) at LTU. A grant for $\$ 745,650$ was executed with LTU on JuTy 15, 1991 . Conference Report 102-177 (Ref. 2) accompanying the Energy and Water Development Appropriations Act, 1992 (Public Law 102-104) indicated that $\$ 10$ million had been included in DOE's fiscal year 1992 appropriation to assist the LTU with construction of the proposed Institute for Micro-manufacturing. A modification to the original grant was made for the additional $\$ 10$ million and executed with the University on April 7, 1992 . Thus, total funding to LTU for the proposed Institute is $\$ 10,745,650$.

Grant funds are available to the University for the limited purpose of performing preliminary studies, including analys is necessary to prepare this environmental assessment. However, under the terms of the grant, the grantee may not initiate construction or take any other action which would affect the environment or limit alternatives until the DOE NEPA process has been completed and DOE has determined that such action should proceed.

\subsection{Project Description}

The main component of the proposed Institute would be a multidisciplinary research, development and instruction facility located at the main campus of LTU, in Ruston, Louisiana. Its focus would be applied research in science and engineering, emphasizing the design and development, testing, assembly, and production of micron and submicron 
structures and devices. The building would be approximately 42,000 gross square feet, with no basement. Construction would be steel frame with brick veneer over drywall back-up. Laboratories and clean rooms for lithography, metrology, and micro-machining would be grouped in a single-story rectangular structure of approximately 19,000 square feet with a clear height of 20 feet. Research and faculty offices, graduate-student cubicle areas, a computer lab, reference areas, meeting rooms/area, and a lecture/presentation hall would be grouped in a two-story structure of approximately 23,000 square feet, joined to the single story structure by a two-story corridor with skylights. The laboratories would have provisions for specialized heating, ventilation and air conditioning and extensive environmental, stabilization, and vibration isolation. The proposed facility would increase campus employment $3 \%$, and campus payroll approximately $9.5 \%$.

The proposed Ruston R\&D facility would have a new dedicated beamline off the electron storage ring at CAMD at LSU in Baton Rouge, Louisiana. This normal-conducting (as opposed to superconducting) electron storage ring is a source of $x$-rays for $x$-ray 7 ithography at the Colleges of Basic Sciences and Engineering at LSU; however, it is not only a university facility but also supports collaborative research on a regional and national basis. The proposal is to install additional equipment for a new beam port and target area. This would include synchrotron beamline apparatus such as an exposure station, resist module, inspection optics, computer station, and general furnishings.

\subsubsection{Construction Activities}

Construction of the proposed Ruston campus R\&D facility (Figures 2 and 3 ) would begin as soon as the NEPA requirements are satisfied. Completion is anticipated in 18. months. Construction machinery involved would include a tower crane, bulldozer, motor grader, paving machine, rubber-tired backhoe, rotary drum roller, and air compressors.

Construction activities would be scheduled Monday through Friday, day shifts only. It is estimated that 100 to 125 construction personnel would work at the site, averaging 30 per day, and peaking at 70 per day near the end of construction.

Construction waste would average 40 to 45 tons per month, consisting of typical construction debris. Waste would be disposed of by the contractor at a local industrial landfill according to local ordinances. The existing drainage pattern for this site is in a southeasterly direction. The storm drainage system will be redesigned, if necessary, to accommodate the additional loading generated by this project. If necessary, a temporary retaining pond will be constructed. Traffic impact would involve normal minor traffic inconveniences occurring during construction. There would be no unique or unusual traffic or noise problems.

The proposed new dedicated beamline off the electron storage ring at CAMD would be housed within the existing building at LSU in Baton Rouge, and therefore construction activities would be limited to equipment furnishing and installation.

\subsubsection{Operation Activities}

There would be four areas of concentration at the proposed Ruston campus R\&D facility:

1. The design and fabrication of micro-devices, such as micro-motors, actuators, sensors, pumps, valves, and connectors.

2. The design and fabrication of microstructures, such as micro-heat exchangers, filters, nozzles for uranium isotope separation, distillation columns, and supports for micro-devices and systems. 
Figure 1. City Location of the Three Components of the Institute for Micro-manufacturing

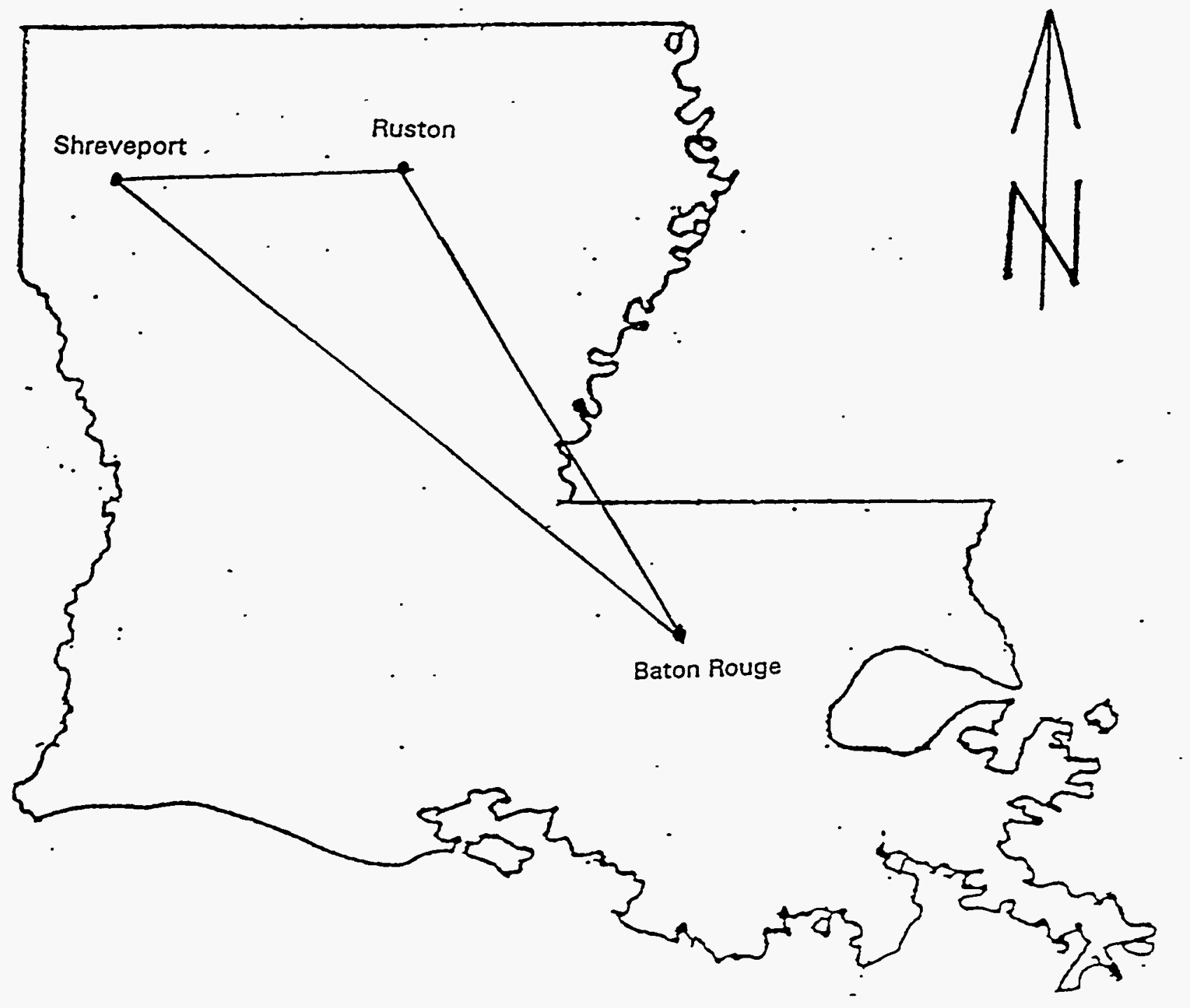

\section{Mrileage}

Shreveport to Baton Rouge . 250

Ruston to Baton Rou:ge . . . 230

Ruston to Sirevezort . . . . 80 


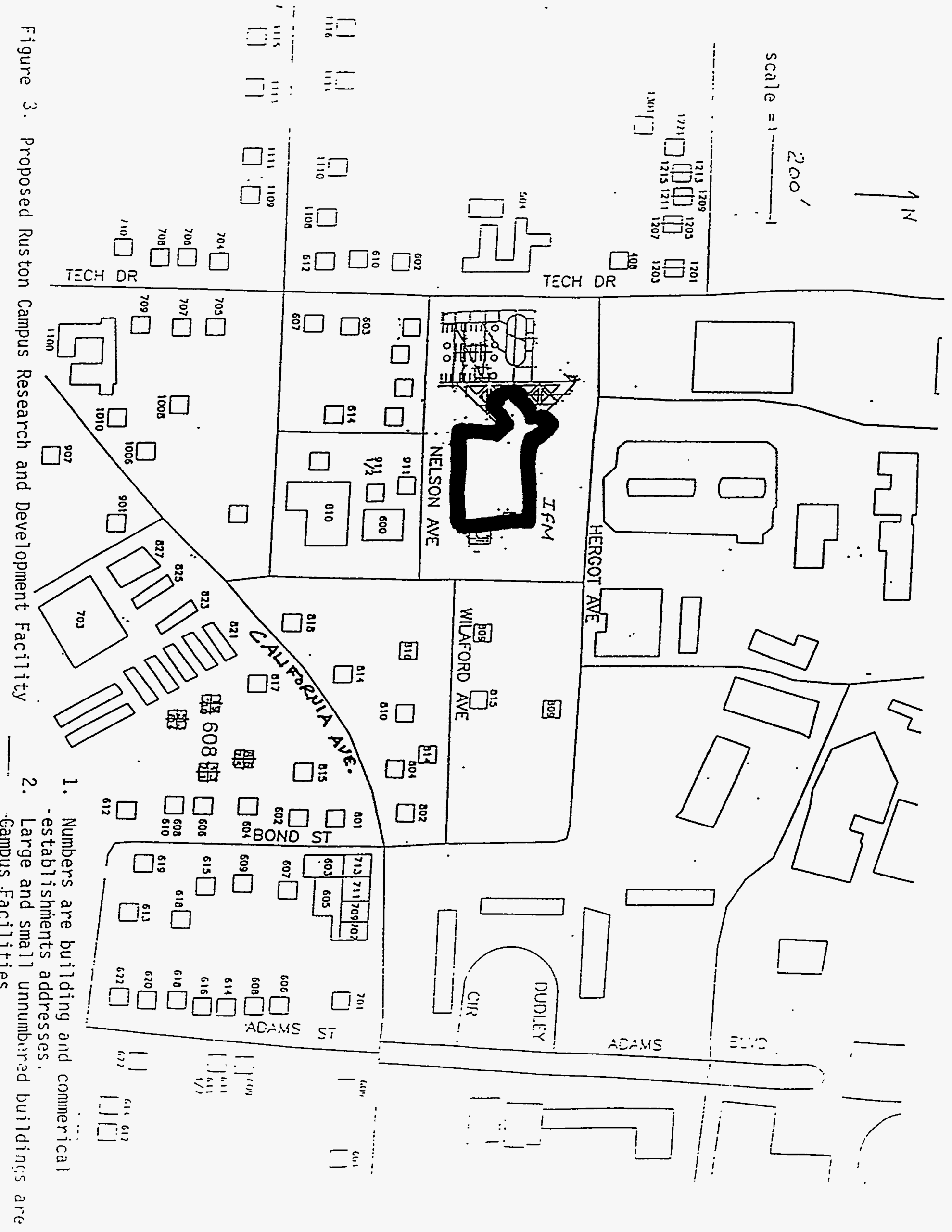


3. Research related directly to the manufacturing process, including fabrication, metrology, assembly, and testing of the micro-products mentioned above.

4. Microsystems research involving the integration of these micro-devices and structures and the interfacing of these systems with the macroscopic world.

The existing diamond-bit machining technology at LTU would be enhanced and used for the fabrication of these micro devices and structures. Also, conventional photo lithography and chemical etching would be adapted for the fabrication of low-aspect ratio devices and structures. (Aspect is the ratio of structure's depth to width. For example, low aspect structures are basically flat.) The research and development would include small machines that could build these small micro-products.

The CAMD component of the proposed action would be a collaborative effort between LSU and LTU. The new beam port would enable LTU to pursue research associated with the $X$-ray lithography micro-machining capability via this "user" facility. Researchers would work on selective etch techniques and X-ray lithography essential for the fabrication of micro devices and structures.

\subsection{No Action Alternative}

Under the no action alternative, DOE would not authorize LTU to proceed with construction or any other action that would affect the environment or limit alternatives. If this should occur, LTU has already committed itself to pursue the project without the federal grant. However, with a reduction in federal funding, a delay may be caused in the project implementation depending upon the access to alternative funding sources. Therefore, the environmental impacts of the no action alternative would be the same as those of the proposed action, although possibly delayed.

\subsection{AFFECTED ENVIRONMENT}

The proposed site for the Ruston campus R\&D facility (shown in Figures 2 and 3 as the heavy outlined area in the center of the map) is a 4.5 acre tract in a built-up area consisting of residences directly to the west and south, and University property to the east, north south and far south (unnumbered areas of Figure 3 ). The natural campus areas adjacent to the proposed site include grasses, shrubbery and trees. Fauna typical of this environment include common local smalt mammals such as squirrels, birds, and insects. The proposed site is wooded and contains 72 trees larger than four inches in diameter, most of which are on the southern half of the property. There are several varieties of oak ranging in size up to 40 inches in diameter. Construction would preserve many trees as part of the landscape, particularly to the south and east of the building. Several trees on or near the building footprint would be removed. The proposed site is not near a Class I Air Quality Control Region. The site has been classified as attainment for all criteria pollutants, and it is unclassified with respect to ozone due to the lack of precursors to indicate a potential problem (Ref. 3, 15).

The environment for the proposed CAMD component would be the existing building and normal conducting compact electron storage ring designed to accommodate user installations. Minimal emission or discharge to the external (campus) environment is anticipated.

\subsection{ENVIRONMENTAL IMPACTS (EFFECTS)}

Sections 5.1 and 5.2 of this report address the potential environmental effects of the proposed Ruston campus R\&D facility; section 5.3 deals with the proposed modification of the CAMD facility in Baton Rouge, Louisiana. 


\subsection{Construction of the Proposed Ruston Campus R\&D Facility}

\subsubsection{Sensitive Resources}

The proposed Ruston campus R\&D facility would have no effect on sensitive resources. There are no known historic/archeological/cultural resources located on or around the proposed site (Ref. 3,5). The proposed site is part of a developed university campus which is not an area that contains proposed or listed Federal- or State-protected species or critical habitats (Ref. 3,6 ).

The average elevation of the proposed site is approximately 350 feet and the 100-year floodplain level nearest the site (3600 feet away) is 269.29 feet. This means the proposed site is equal or greater than 80.71 feet above the 100-year flood. The proposed action does not constitute a "critical action" requiring consideration of the 500-year floodplain under DOE Regulations, Part 1022 of Ti.tle 10 of the Code of Federal Regulations (10 CFR Part 1022) (Ref. 3, 7). The proposed site does not contain designated wetlands, nor does it lie in the coastal zone (Ref. 3, 8, 17). There are no state or national forests, parks, trails, or other protected features such as wild and scenic rivers in the contiguous areas or areas of effect of the proposed site (Ref. 3,6, 9). The proposed site was previously zoned "A-2" residential by the Ruston Planning Commission and the proposed action would not affect prime or unique farmland (Ref. 3, 18). The town of Ruston uses drinking water originating from the Sparta Aquifer, which is not designated as a sole source aquifer by the United States Environmental Protection Agency (EPA).

\subsubsection{Erosion/Run-Off}

The proposed site slopes gently from the Northwest to the Southeast corner, with a total elevation differential of 15 feet. Erosion and runoff would be controlled during construction using conventional siltation/erosion engineering controls, such as retention ponds. Design of erosion/runoff mitigation measures would take into account the City of Ruston's storm drainage system characteristics (Ref. 3).

\subsubsection{Spoits Disposal}

\subsubsection{Asbestos}

There would be no asbestos associated with the proposed project, which involves only new construction and no alteration or demolition of existing support structures (Ref. l).

\subsubsection{Excavation Waste/Disturbance of Contaminated Soil}

The existing soil at the proposed site is uncontaminated by prior land use activities (Ref. 3, 4). Previous buildings at the proposed site were already demolished before LTU acquired the land. Excavation and other construction wastes (approximately 5 tons) would be disposed of by the contractor at a state-approved landfill that under the contract would be determined by the contractor (Ref. 4).

\subsubsection{Demolition/Construction Haste}

No demolition is required, because the site proposed is vacant land. By terms of the contract, construction waste would be disposed of by the contractor and in accordance with local ordinances. It is estimated that approximately 2000 cubic yards of waste material would be generated during construction (Ref. 4).

5.1.4 Air Quality Impacts (Dust, Equipment Emissions) 
Construction would produce temporary emissions associated with conventional construction machinery and construction-induced traffic. No permit would be required for this activity (Ref. 3, 4).

\section{1 .5 Noise}

Construction would produce temporary noise disturbances associated with construction machinery and construction-induced traffic. Typical machinery would include bulldozers, a small mobile crane, and air compressors (Ref. 3,4). Typical noise level for a bulldozer would be 107 decibels $(\mathrm{dB})$ at the source, 87-102 dB at 50 ft, 81-96 dB at $110 \mathrm{ft}, 75-90 \mathrm{~dB}$ at $200 \mathrm{ft}$, and $69-84 \mathrm{~dB}$ at $400 \mathrm{ft}$. These levels compare to the pain threshold of $125 \mathrm{~dB}$, and an annoyance threshold of $65 \mathrm{~dB}$. At these levels persons outdoors within a $400-\mathrm{foot}$ radius of the source, assuming no topographic attenuation, would experience noise in the annoyance range of 65 to $125 \mathrm{~dB}$. Within a $200 \mathrm{ft}$ Radius from the center of the site, there would not be any noise annoyances since the approximately size of the site is $350 \mathrm{ft}$ by $600 \mathrm{ft}$, but within a $400 \mathrm{ft}$ Radius, it appears that 6 private residences and 2 campus facilities could be affected in the 69-84 dB range. For persons indoors, these levels would be considerably attenuated depending upon the acoustical insulation properties of walls and windows (Ref. 16). These sources of noise would be intermittent and temporary during land grading and structure assembly. All construction activities would be limited to normal working hours during the daytime and work would be scheduled Monday through Friday day shifts only.

\subsubsection{Transportation, Traffic, Parking, Relocation}

Construction would generate occasional traffic inconveniences along Tech Drive, Hergot Avenue, and Nelson Avenue, when certain material deliveries would be made. However, it would not cause unique or unusual traffic problems, since there would be ready access to alternative public routes. Construction-related traffic would peak at about 25 trips per day (Ref. 3, 4).

Parking during construction would not pose a problem, since there is adequate existing parking in a lot adjacent to the site.

The project not expected to require the relocation of any residences, workplaces or utilities since the site is currently vacant land.

\subsection{Operation of the Proposed Ruston Campus Research and Development Facility}

\subsubsection{Domestic Waste (Trash)}

The proposed Ruston campus R\&D facility would produce approximately 18.25 tons/year of conventional solid waste to be picked up by the City of Ruston Public Works Department for disposal at the Lincoln Parish Landfill. The additional solid waste load would be readily accommodated by the local municipal/private solid waste disposal system (Ref. 3, 4, 11, $19,20)$.

\subsubsection{Sanitary Waste (Laboratory Waste)}

The proposed Ruston campus R\&D facility would produce approximately 2000 gallons per day of sanitary sewage associated with approximately 70 full-time employees plus 60 students and 27 faculty members. This additional load would be discharged to the sewerage system operated by the City of Ruston Public Works Department. The proposed increased sewage load represents approximately $1 \%$ of the current University load and would be accommodated by the municipal sewerage system (Ref. 3, 4, 11). 


\subsubsection{Hazardous Waste}

The following hazardous wastes would be generated by the proposed Ruston campus R\&D facility as compared to the current generation on campus. The units are in kilograms per month $(\mathrm{kg} / \mathrm{mo})$ : (Ref. 21)

\begin{tabular}{|l|c|c|c|c||}
\hline \multicolumn{1}{|c|}{ CHEMICAL HASTE } & $\begin{array}{c}\mathrm{kg} / \mathrm{mo} \\
\text { PROJECT }\end{array}$ & $\begin{array}{c}\mathrm{kg} / \mathrm{mo} \\
\text { CAMPUS }\end{array}$ & $\begin{array}{c}\text { PROPOSED } \\
\text { NEW TOTAL }\end{array}$ & EPA* STREAM \\
\hline \hline $\begin{array}{l}\text { Dilute Hydrofluoric } \\
\text { Acids }\end{array}$ & 5.90 & 0.0 & 5.90 & $\mathrm{U} 134$ \\
\hline $\begin{array}{l}\text { Other Dilute. Acids } \\
\text { and Caustics }\end{array}$ & 7.95 & 9.6 & 17.55 & $\mathrm{D} 002$ \\
\hline Trichloroethylene & 3.95 & 0.0 & 3.95 & $\mathrm{U} 228$ \\
\hline Other Solvents & 5.90 & 34.7 & 40.6 & D 001 \\
\hline Other Chemicals & 3.18 & 26.5 & 29.68 & various \\
\hline
\end{tabular}

* EPA Hazardous Waste Number per EPA Regulation 40 CFR Part 26, Subpart C.

Total University hazardous waste disposal was $70.8 \mathrm{~kg} / \mathrm{mo}$ in 1992 , which would be increased by $26.88 \mathrm{~kg} / \mathrm{mo}$ or about $38 \%$. Hazardous wastes at the University are managed in compliance with applicable Federal and State regulations and standards. The University has a hazardous waste management program and requires all on-site generators to follow specific guidelines and procedures (Ref. 12).

Under EPA Identification No. LAD 981598 543, the University is classified as a small quantity generator, producing less than $1000 \mathrm{~kg}$ of hazardous waste per month. The increment of the project would not change the University's small quantity generator status (Ref. 21). This plan is in compliance with Federal Hazardous Waste Regulations, and would apply to the proposed Institute.

As a small quantity generator the University is allowed to store hazardous materials on-site for up to 270 days (because the disposal site is greater than 200 miles off-site.) Pickups of hazardous chemical for on-site storage are performed monthly by the University's Department of Environmental Safety, according to procedures described in the Louisiana Tech University Hazardous Chemical Management Plan (Ref. 3, 4, 12). Pickups of hazardous chemicals at the University's site are performed twice annually by Rollins Chempak Inc., (EPA ID No. 985171255 ) for disposal by Rollins Environmental Services (LA), Inc., (EPA ID No. LAD 010395 127).

\subsubsection{Biological/Medical Waste}

The proposed Ruston campus R\&D facility would not produce any biological or medical wastes (Ref. 3, 4).

\subsubsection{Radioactive and Mixed/Hazardous/Radioactive Waste}

The proposed Ruston Campus R\&D facility would not produce regulated radioactive or radioactive mixed wastes (Ref. 3 ). 


\subsubsection{Radiation Exposures}

Operation of the proposed Ruston R\&D facility would not involve radiation-emitting processes (Ref. 3).

\subsubsection{Air Emissions}

\subsubsection{Radiation}

The proposed Ruston R\&D facility would not be a source for potential air emissions of radioactive substances (Ref. 3 ).

\subsubsection{Criteria Pollutants}

The proposed Ruston campus R\&D facility would be supplied with power and heat distributed from a central campus power plant using approximately 70,000 dry million British Thermal Units (mmBTUs) of natural gas per month. The proposed facility would increase the load by 2100 mmBTUs per month or approximately $3 \%$.

The proposed facility would not be located in or affect a non-attainment area (Ref. 15). Moreover, the site would not impact a Class I Air Quality Control Region. The proposed site has been classified as attainment for all criteria pollutants, and it is unclassified with respect to ozone due to the lack of precursors to indicate a potential problem (Ref. $3,15)$.

\subsubsection{Toxic Compounds Released to the Air}

The following chemicals including toxic materials are anticipated to be used by the proposed Ruston campus R\&D facility $(T=$ Toxic, $C=$ Corrosive, $F=F l$ ammable, $P=$ Pyrophoric) (Ref. 3, 13):

- Gaseous: Chlorine (T), Hydrogen Chloride (T), Silane (T,F,P), Silicon Tetrachioride $(C)$, Bromine $(C, T)$, Sulfur Hexafluoride $(T)$, Hydrogen $(F)$

- Solvent: Acetone (F), Chloroform (T), Methyl Alcohol (F), Isopropyl Alcohol $(F)$, Toluene (F), Xylenes (F), Trichloroethylene (T)

- Liquid Chemical: Acetic Acid (C), Hydrochloric Acid (C,T), Hydrofluoric Acid $(C, T)$, Phosphoric Acid (C), Sulfuric Acid (C), Nitric Acid (C), Ammonium Hydroxide (C), Potassium Hydroxide (C), Sodium Hydroxide (C), Hydrogen Peroxide (C), Polyamide

- Metal: Aluminum, Copper, Gallium, Germanium, Gold, Antimony (T), Arsenic (T), Gallium Arsenide (T), Indium Arsenide (T), Lead (T), Nickel (T), Tungsten (T), Chromium (C), Titanium (C)

Geraghty \& Miller (G\&M), environmental consultants to the University, estimated quantitative releases for each of the above materials and carried out a dispersion analysis to determine the probable exposure levels to persons outside the building under two scenarios: "realistic operations" and "worst case" (Ref. 13). In addition, they analyzed accidental releases under two scenarios: "realistic" and "worst case."

None of the above constituents are subject to emission limits in 40 CFR Part 61 - National Emission Standards for Hazardous Air Pollutants. Therefore, G\&M assessed the modeling results using the following sources: 
- Table 51.2 Louisiana Toxic Air Pollutant Ambient Air Standards from Louisiana Air Code 33:III Chapter 51

- Threshold Limit Values (TLV) from Sax's Dangerous Properties of Industrial Materials

- Lawrence Livermore National Laboratory's (LLNL) Safety Analysis Document for the LLNL Electronics Engineering Micro-fabrication Facility, Building 135

The results, summarized on Table 5-1, are in terms of projected maximum emission rate over an 8-hour period versus the emission rate required to exceed TLVs. In all cases G\&M, using conservative assumptions that biased model results upward, found the projected emissions would be at least four orders of magnitude less than the emission levels that would produce Threshold Limit Values of exposure in the air environment.

After reviewing the possible causes of accidents that could result in a release of toxic gases, it has been concluded that the overall risk is negligible (i.e., four orders of magnitude less than the TLVs listed in Sax's Dangerous Properties of Industrial Materials) and the impacts from potential exposure of the public and workers due to atmospheric venting would be minimal. Currently the University does not release any Volatile Organic Compounds (VOC) or any other inorganic chemicals to the atmosphere. The estimated releases for the proposed project are 0.04 tons per year of VOCs and 0.05 tons per year of other inorganic chemicals. These estimated releases are sufficiently low enough for LTU to request a Small Source Exemption from the Louisiana Department of Environmental Quality, Air Quality Division permitting and reporting requirements (Ref. 13). This exemption was granted to the University on July 7, 1994, by the State of Louisiana Department of environmental quality (Appendix A).

\section{2 .8 Noise}

The interior building mechanical systems noise contribution, such as fans and compressors, would be placed in industry-standard noise absorption enclosures and rooms, with minimal adverse effects on the environment, personnel, or research activities (Ref. 3).

\subsubsection{Socioeconomic Impacts}

Community reaction to the proposal for the Ruston campus R\&D facility has been positive (Ref. 3), and the Mayor of Ruston has provided a letter supporting the proposed project (Ref. 14). The proposed project would have both short- and long-term beneficial effects on the local economy and would contribute to the diversification of the Louisiana economy through increased employment and stimulation of new high technology investment (Ref. 3 ). Direct employment would be approximately 70 employees with an annual payroll of close to $\$ 2$ million, 27 staff members with annual payroll of $\$ 1,350,000$ and 60 graduate students with annual payroll of $\$ 640,000$ (Ref. 4). The University current7y has 3100 employees and a gross payroll of approximate 1 y $\$ 42$ million (Ref. 4).

\subsubsection{Accident Analys is}

Potential accidents scenarios are those that would release hazardous materials into the environment causing death, personal injury, property destruction, and damage to environmental resources. The risk of accidents occurring would be minimized by structural and mechanical features that are part of the design of the proposed Ruston campus R\&D facility (Ref. 4), and by the University's Hazardous Chemical Waste Program (Ref. 12). This program includes procedures that would mitigate and minimize the consequences of potential accidents from these sources. 
Three types of accidents are reasonably foreseeable: (1) toxic air emissions; (2) hazardous

chemical spills and releases, and (3) fires. The range of gases and liquids that would be

Table 5-1: Projected Hazardous Air Emissions Versus Emissions Required to Exceed Threshold Limit Values

\begin{tabular}{||l|c|c|}
\hline \multicolumn{1}{|c|}{ SUBSTANCE } & $\begin{array}{c}\text { PROJECTED } \\
\text { (grams/second) }\end{array}$ & $\begin{array}{c}\text { REQUIRED TO EXCEED TLV } \\
\text { (grams/second) }\end{array}$ \\
\hline \hline Gaseous: & .006 & 55.17 \\
\hline Chlorine & .001 & 275.84 \\
\hline Hydrogen Chloride & .001 & 242.74 \\
\hline Silane & .019 & - \\
\hline Silicon Tetrachloride & .007 & $36,778.23$ \\
\hline Sulfur Hexafluoride & .009 & 24.27 \\
\hline Bromine & .000 & - \\
\hline Hydrogen & .019 & $65,465.24$ \\
\hline Liquid Solvents: & .012 & $1,802.13$ \\
\hline Acetone & .010 & $9,635.90$ \\
\hline Chloroform & .019 & $36,153.00$ \\
\hline Methyl Alcohol & .003 & $5,516.73$ \\
\hline Isopropyl Alcohol & .003 & $15,961.75$ \\
\hline Toluene & .042 & $12,467.82$ \\
\hline Xylenes & .005 & 919.46 \\
\hline Trichloroethylene & .013 & 275.84 \\
\hline Liquid Chemicals & .006 & 95.62 \\
\hline Acetic Acid & .005 & 36.78 \\
\hline Hydrochloric Acid & .003 & 36.78 \\
\hline Hydrofluoric Acid & .004 & 191.25 \\
\hline Phosphoric Acid & .006 & - \\
\hline Sulfuric Acid & .003 & 73.56 \\
\hline Nitric Acid & .006 & 73.56 \\
\hline Ammonium Hydroxide & .003 & 51.49 \\
\hline Potassium Hydroxide & .003 & - \\
\hline Sodium Hydroxide & .0001 & \\
\hline Hydrogen Peroxide & & \\
\hline Polyamide & .75 .90 \\
\hline All Metals: & & \\
\hline
\end{tabular}

subject to accidental release or spill are described in Section 5.2.7.3. Fires could result from equipment failure, electrical short circuits, or ignition of the flammable materials described earlier in this document. To prevent and mitigate these occurrences, the building will be designed per DOE 6430.1A, National Fire Protection Association 
Uniform Building Code, Factory Mutual and National Electrical Code standards. If a room or equipment fire were to occur, wet pipe fire sprinklers would be activated, and hand fire extinguishers would be readily available to personnel to extinguish small fires. Fire rated walls and doors would prevent or inhibit spread of the fire beyond a contained area, and the smoke removal system would be activated. The building would be equipped with properly designed emergency lighting and exits pursuant to applicable fire safety standards.

In the past ten years the University has had no fires or other reportable accidents associated with laboratory activities. (Minor accidents that are treated with first aid measures and do not require medical attention are not considered "reportable.") (Ref. 4). Based upon this record, it is expected that no reportable accidents are unlikely to occur at the proposed Ruston campus R\&D facility's activities.

\subsubsection{Pesticides}

Pesticide use for termite control would be performed by licensed bonded pest control companies (Ref. 3).

\subsubsection{Storage Tanks}

There would be a 550 gallon above ground diesel storage tank to fuel an emergency generator. Design of the tank will incorporate Spi11 Prevention, Control and Countermeasure requirements under the Clean water Act (Ref. 3 ).

\subsubsection{Hazardous Material Storage}

All hazardous materials would be stored at the point-of-use according to all University procedures set forth by the Environmental/Safety Department. The building would have an area for solvent, chemical, and gas cylinder storage. All are designed with extensive safety precaution in mind. Monitors would be installed where toxic gases are being used or stored (Ref. 3).

Solvents such as acetone, chloroform, methyl alcohol, and isopropyl alcohol would be purchased and stored in 5 gallon containers; a maximum of 20 gallons would be in storage at any one time. None of the other solvents shown on Table 5-1 would be stored in quantities greater than 2 liters. Solid materials would be purchased in one-pound quantities with a maximum storage of 10 pounds of any listed substance (Ref. 4).

Cylinder storage, solvent storage, and chemical reagent storage would be located adjacent to the building in designated storage areas built with special safety measures including: sloped floors to direct spills to containment areas for subsequent collection, explosion-proof electrical equipment and fixtures. As containers of chemicals are moved into the laboratory areas, they would be stored in approved cabinets for flammable materials or other approved areas, as prescribed by the University Safety Manual (Ref. 4).

\subsection{Installation and Operation of the Proposed Beamline at the Center for Advanced Microstructures and Devices}

The CAMD facility was constructed by LSU in 1991 under a grant from DOE. NEPA review for the 1991 project resulted in a DOE determination of "clearly no significant impact", which was documented on August 4, 1990 by the Manager of the Chicago Operations Office, prior to initiation of construction (Ref. $24 \& 25$ ). 
The only construction associated with creation of a new dedicated beamline off the electron storage ring at CAMD would be equipment assembly at the beam port to direct the beam to designated target areas. This activity would take place within the existing building at LSU in Baton Rouge, and therefore would have little potential for impact on the environment. Operation of the proposed new beamline would have a potential for local exposure of operating personnel to radiation. Test results from within the CAMD show that the annual cumulative dose for the facility and for the individual are $0.001 \mathrm{rem} /$ year. Test results on beamlines comparable to the one LTU would be installing, confirm that the proposed beamline's annual cumulative dose would also be $0.001 \mathrm{rem} /$ year. Therefore, by combining the beamline dose, the average facility dose and an annual cumulative background dose of $0.360 \mathrm{rem} /$ year, the estimated cumulative dose for a worker at the proposed facility would be $0.362 \mathrm{rem} /$ year compared to the guideline in DOE Order 5480.11 of 5.0 rem/year. The CAMD activities are covered under the Radiation Safety Program administered by LSU's Safety Department in compliance with applicable Federal and state regulations. Safety guidelines associated with radiation exposure are detailed in the LSU's Environmental Health and Safety Manual. LSU's Radiation Safety Officer is in charge of all safety aspects at the CAMD facility, including the proposed new beamline component (Ref. 3).

\subsection{Cumulative Impacts}

Construction of the two proposed components would have no cumulative impacts due to their limited magnitude and the distance between them. For the same reasons, operation of the LSU and LTU facilities would have no cumulative environmental impacts. Operations of the proposed facilities have little or no cumulative impact on existing, ongoing activities on the campuses. The small scale research proposed for the proposed Ruston campus R\&D facility at the Ruston campus would be the same type (materials science) that already is being preformed at other facilities on the Ruston campus, without environmental, health, or safety effects. The installation and operation of the newly proposed equipment at the CAMD facility in Baton Rouge, would be of the same type already in use, and within the parameters and use expectations previously established for the operation of that facility.

\subsection{Compliance with Regulations}

The University has met with State of Louisiana Department of Environmental Quality officials. At this time no additional permits are known to be required by the Department of Environmental Quality for either of the facilities. The proposed Ruston campus R\&D facility would not require any modification to LTU's hazardous waste generator status according to State and Federal guidelines (Ref. 3).

\subsection{RELATIONSHIP OF PROPOSED ACTION TO OTHER ACTIONS AND ACTIONS BEING CONSIDERED UNDER OTHER NATIONAL ENVIRONMENTAL POLICY ACT REVIEWS}

As previously indicated, one proposed component of the proposed action is related to the CAMD facility, construction and operation of which received DOE NEPA review in 1990. The proposed action. is not related to other actions being considered under NEPA reviews currently in process.

\subsection{RELATIONSHIP OF THE PROPOSED ACTION TO ANY APPLICABLE FEDERAL, STATE, REGIONAL, OR LOCAL LAND USE PLANS AND POLICIES LIKELY TO BE AFFECTED}

The proposed action would be on university properties and are part of plans for expanding university research activities. University activities are consistent with applicable federal, state, and local land use plans and policies. 


\subsection{LISTING OF AGENCIES AND PERSONS CONSULTED}

State of Louisiana, Department of Culture, Recreation and Tourism, Mark H. Hilzim, Secretary

State of Louisiana, Department of Wildlife and Fisheries, Gary D. Lester, Coordinator, Louisiana Natural Heritage Program

Department of the Army, Vicksburg District Corps of Engineers, Kenneth P. Mosely, Chief, Enforcement Section, Regulatory Branch

U.S. Fish and Wild7ife Service, Lafayette, Louisiana, Russell C. Watson, Acting Field Supervisor

State of Louisiana, Department of Environmental Quality, J. Dale Givens, Assistant Secretary, Office of Water Resources

City of Ruston, Donald G. Adams, PhD, Administrative Assistant (to the Mayor) for Environmenta] Issues

City of Ruston, A. L. Brewer, Public Works Director

Hilda Taylor Perritt, Mayor of Ruston, Louisiana, Letter of December 9, 1992

State of Louisiana, Department of Environmental Quality, Gustave Von Bodungen, PE, Assistant Secretary

State of Louisiana, Department of Natural Resources, Terry W. Howey, Director

Lincoln Parish Police Jury, Robert W. Turner, Solid Waste Superintendent, Lincoln Parish Landfil1

\subsection{REFERENCES}

1. Senate Report 101-378, Accompanying the Energy and Water Development Appropriations Act, 1991 (Public Law 101-514), Senate Committee on Appropriations

2. Conference Report 102-177 Accompanying the Energy and Water Development Appropriations Act, 1992 (Public Law 102-104)

3. Environmental Report, Design and Construction of the Institute for Micro-manufacturing, Louisiana Tech University, Ruston, LA, December 1992, Submitted by Dr. Roy W. Dowling, Director, Environmental Health \& Safety Department, LTU

4. Memoranda to Fred March, Senior Engineer Los Alamos Technical Associates from Dr. Roy W. Dowling, Director, Environmental Health \& Safety Department, March 19 \& 31 , 1993 containing supplementary information to the Environmental Report and other representations.

5. State of Louisiana, Department of Culture, Recreation and Tourism, Mark H. Hilzim, Secretary, Letter of November 5, 1992, Subject: Cultural Resources

6. State of Louisiana, Department of Wildlife and Fisheries, Gary D. Lester, Coordinator, Louisiana Natural Heritage Program, Letter of October 30, 1992, Subject: Rare, threatened or endangered species 
7. National Flood Insurance Rate Map, City of Ruston, Louisiana, Lincoln Parish, Panel 3 of 6, Community Panel Number 2203570003 B, Effective Date: June 15, 1981

8. Department of the Army, Vicksburg District Corps of Engineers, Kenneth P. Mosely, Chief, Enforcement Section, Regulatory Branch, Letter of November 18, 1992, Subject: Permitting requirements (wetlands)

9. U.S. Fish and Hildlife Service, Lafayette, Louisiana Russell C. Watson, Acting Field Supervisor, Representation on November 6, 1992 appended to LTU letter of October 12, 1992

10. State of Louisiana, Department of Environmental Quality, J. Dale Givens, Assistant Secretary, Office of Water Resources, Letter of October 29, 1992, Subject: Drinking Water aquifer

11. City of Ruston, Donald G. Adams, PhD, Administrative Assistant (to the Mayor) for Environmental Issues, Letter of December 11, 1992, Subject: Sewage discharge

12. Louisiana Tech University, Hazardous Chemical Waste Program Guidelines and Procedures, Revised October 2, 1992

13. Geraghty \& Miller Inc., Air Pollution Hazard Analysis (for the Institute for - Micro-manufacturing), December 15, 1992

14. Hilda Taylor Perritt, Mayor of Ruston, Louisiana, Letter of December 9, 1992 , Subject: Support for micro-manufacturing facility

15. State of Louisiana, Department of Environmental Quality, Gustave Von Bodungen, PE, Assistant Secretary, Letter of November 5, 1992, Subject: Ozone Monitoring

16. Environmental Impact Data Book, Jack Golden et al., Ann Arbor Science, 1979

17. State of Louisiana, Department of Natural Resources, Terry M. Howey, Director Coastal Management Division, Letter of October 16, 1992, Subject: Coastal Zone Review

18. U.S. Department of Agriculture, Letter attesting that project would not affect prime farmi and, Apri 9, 1993

19. City of Ruston, Department of Public Works, A.L. Brewer, Director, Letter March 30 , 1993, Subject: Sol id Waste

20. Lincoln Parish Police Jury, Lincoln Parish Landfill, Robert W. Turner, Solid Waste Superintendent, Letter of March, 1993, Subject: Solid Waste

21. Letter to. Fred March, from Dr. Roy W. Dowling, Environmental Safety Department, Director, April 16, 1993 containing information about hazardous wastes to the Environmental Report and other representations by $\mathrm{Dr}$. Dowling

22. Letter to Fred March, from Dr. Roy H. Dowling, Environmental Safety Department, Director, November 2, 1993, containing information relating to construction manpower, construction waste and exposures on the CAMD beaml ine 
23. Department of Energy, Chicago Operations (DOE/CH), Memorandum to Hilary J. Rauch, Manager from Roger A. Mayes, Director Environment, Safety and Health Division, August 4, 1988, Subject: Finding that Proposed Action for the CAMD Facility at LSU in Baton Rouge, LA., does not warrant preparation of an Environmental Assessment (EA) or an Environmental Impact Statement (EIS)

24. DOE/CH, memorandum, from H. J. Rauch, Manager, and J. Nelson, NEPA

Compliance Officer to J. Decker, May 4, 1990, Subject: Finding that Proposed Action for the CAMD Facility at LSU in Baton Rouge, LA., does not warrant preparation of an EA or EIS

25. Letter from J. Decker to C. Borgstrom, Director, Office of NEPA Project Assistance. May 11, 1990, Subject: Approval of MTF for LSU to construct the CAMD facility in Baton Rouge, LA.

26. DOE Implementing Procedures, 10 CFR 1021, Subpart D, Appendix B, Section 1.15. 
APPENDIX A

RESPONSES FROM THE STATE OF LOUISIANA'S REVIEW OF THE ENVIRONMENTAL ASSESSMENT FOR

THE PROPOSED INSTITUTE FOR MICRO-MANUFACTURING

LOUISIANA TECHNICAL UNIVERSITY 


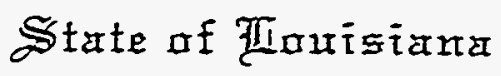

OFFICE OF THE GOVERNOR

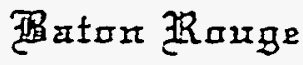

70804-9004

POST OFF:CE $80 \times 84004$ (504) $342-7015$

\section{VIA FACSIMILE}

July 6,1994

Martha A. Krebs

Director

Office of Energy Research

U.S. Department of Energy

-Washington, D.C. 20585

I have received your letter dated June 14, 1994, in regards to Louisiana Tech University's Institute of Micromanufacturingfacility and the Environmental Assessment. I shared the Environmental Assessment with certain divisions at the Iouisiana Department of Environmental Quality. Please find responses attached from those offices.

When these matters in the letters have been addressed, we look forward to moving along with the proposal.

I have no further comments. However, if I may further assist you please contact me at (504)922-3252.

$\therefore$

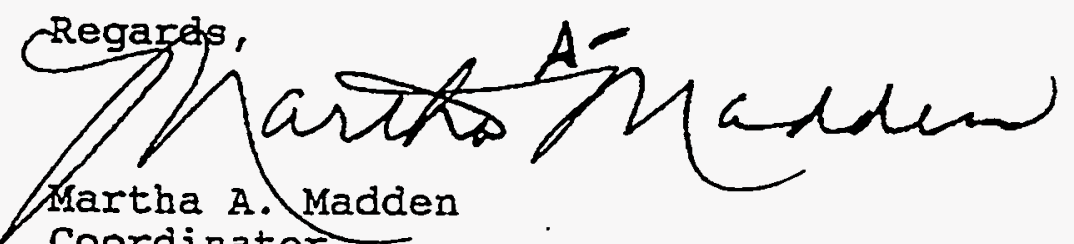

Coordinator

Governor's Office of Permits

MAM/ami

Attachments

CC: Roy Dowling

Louisiana Tech University

P.O. Box 3157

Ruston, LA 71272-0001. 


\section{State of Louisiana}

\section{Department of Eavironmental Quality}

Edwin W. Edwards

Goyemor

Wvliam A. Kucharski secretary

June 22, 1994

MEIYORANDUM

To:

Hs. Hattha Madien

Governor's office of permits

From:

Gustave A. Von Bodungen

Assistant secretary

Re: Proposed construction and operation of Louisiana Tech's Institute for wicromanufacturing facility

The Department of Environmental Quality, Aix quality Division has reviewed the referenced submittal. Louisiana Tech University should apply for an air permit to construct and operate the micromanufactaring facility as required by IAC 33 :III.501.C.

Coples of the referenced subuittal was forwarded to the office of Solid and Hazardous Waste and the office of pater Resources for their review.

An Application for Approval of Emissions and an zmissions Inventory Questionnaire is attached. Please let us know if wo can further assist you.

GVB : TDC 


\section{State of Louisiana}

\section{Department of Environmental Quality}

Edwin W. Edwards

Govemor
William A. Kucharski Secretary

June 23, 1994

Martha Madden, Coordinator

Governor's Office of Permits

Post Office Box 9495

Baton Rouge, Louisiana 70804

- Subject: $\quad$ "Environmental Assessment for Institute for Micro-Manufacturing at Louisiana Tech University" by US Department of Energy, dated April 1994

Dear Ms. Madden:

This is to advise you that the Office of Solid and Hazardous Waste has reviewed the mentioned document, an environmental impact statement required under the National Environmental Policy Act. We have no comments.

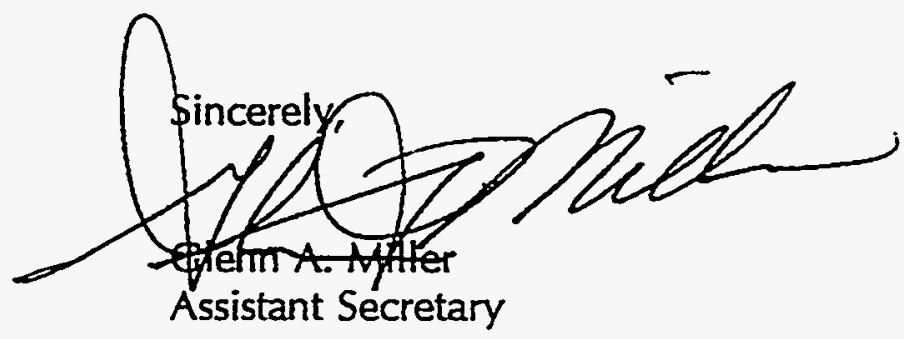

GAM:LHB:KL:MB 


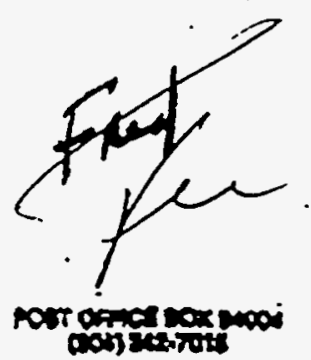

Taly 7, 1994

Kaxtha A. Exuba

Director

Oefice of Bnergy Research

U.8. Depurtinent of Bnorgr

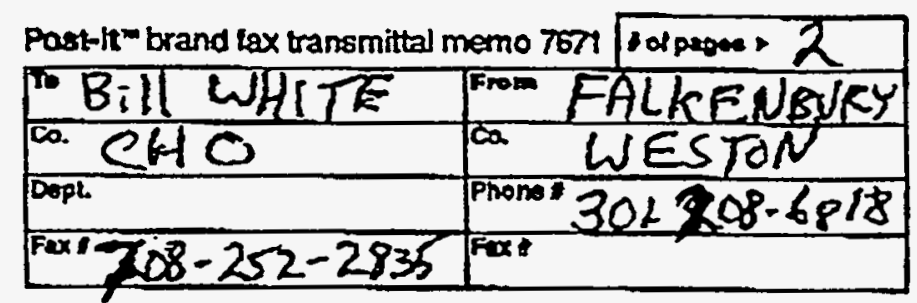

Vashington, D.C. 20585

sabjoot: Updated Intormation on the Enviromontal assosonont for tho Ingtitute for Hicronanakncturing at Lovielana rech Ualvaraits.

Daver II Irebu:

I an anclosing a copy of corrompondence I received today,

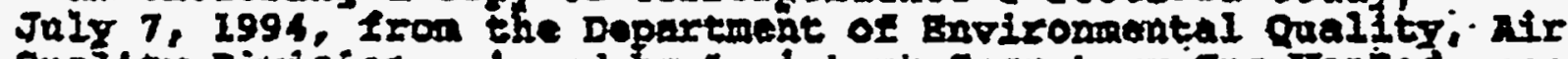

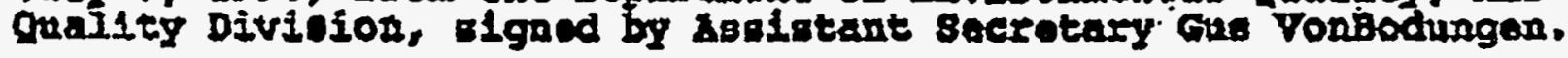

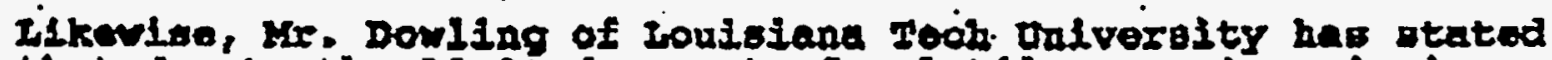
that due to the Iinited anount of volatile organic anissions, tho laojilty has boen glven a mall wource oxemption fran the Iorialane Department of Eavironmantal ouallty.

I an requenting that your offlias note the attached exumption for Iurther assesament of this proporal.

should you have ang quent $10 \mathrm{~m}$ or comanto regarding thlo matter, plenee call me at (504)922-3252.

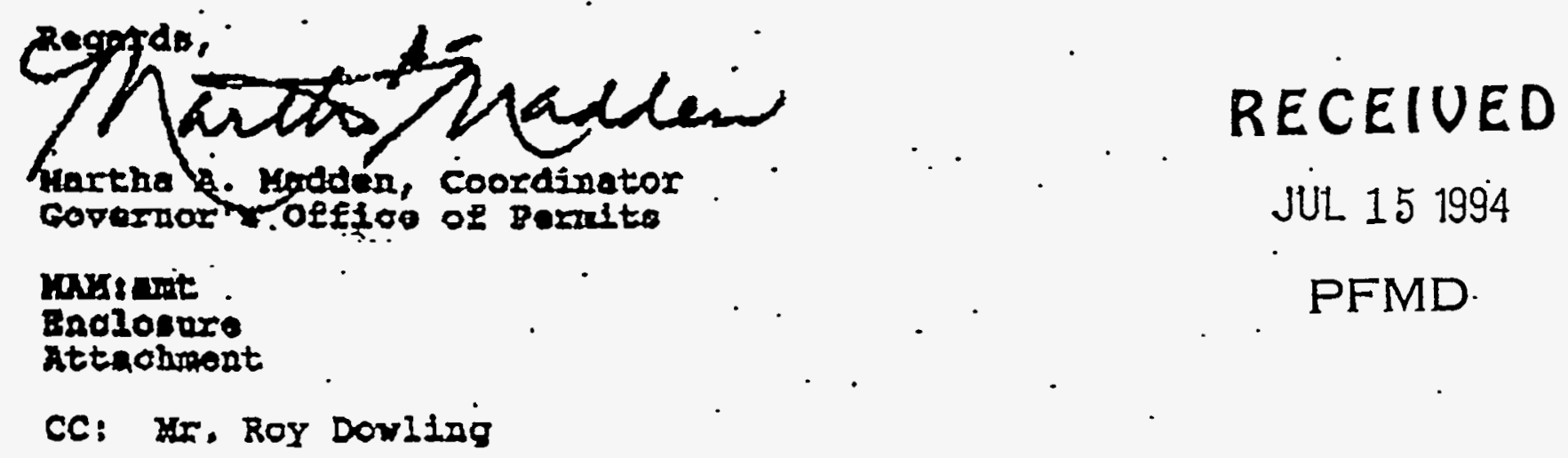


SEVT BY: RESTON - KMAO

HL-87-15y4 2x: कs

\section{State of Loulsiana}

Bepartment of Enstronmontal Qually

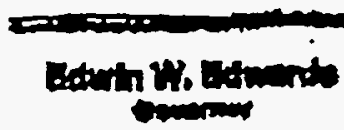

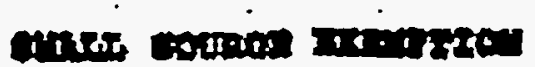

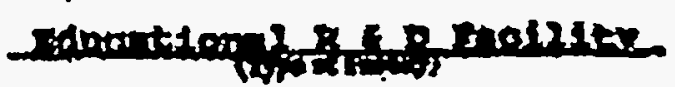
asoming

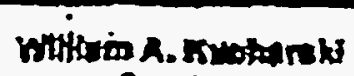

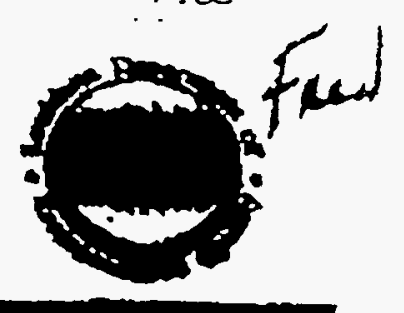

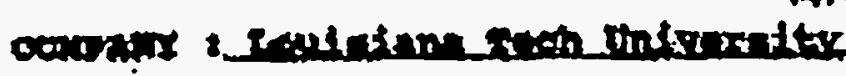

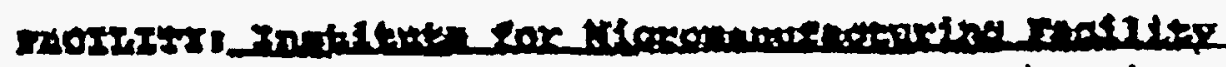

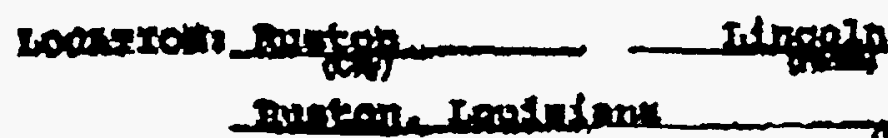

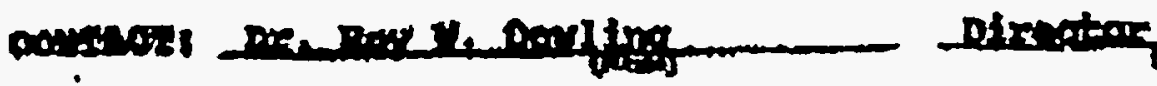

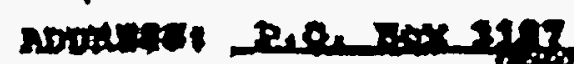

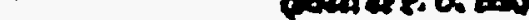

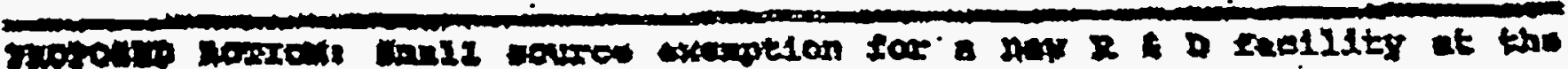

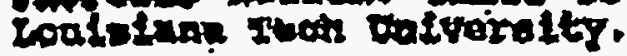

montongen

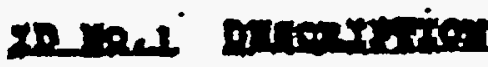
mix ory. 2ny

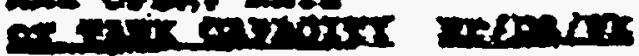

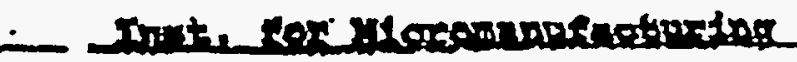
3.?.
$25 / 4 / 58$.

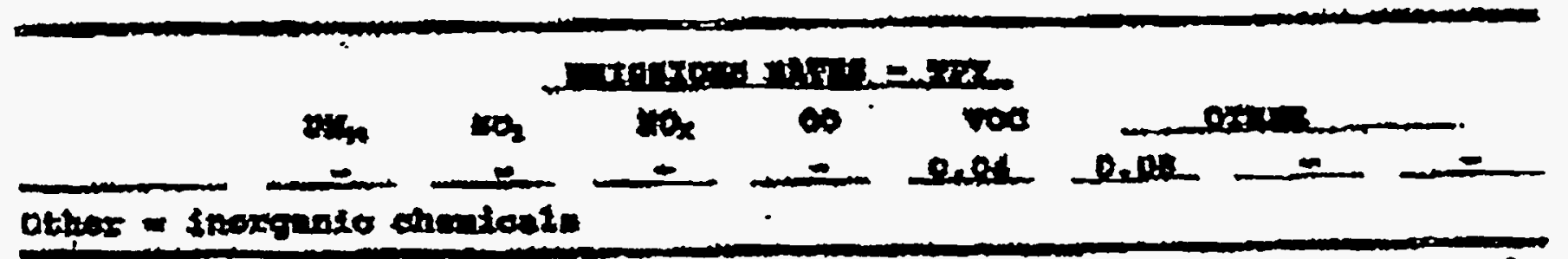

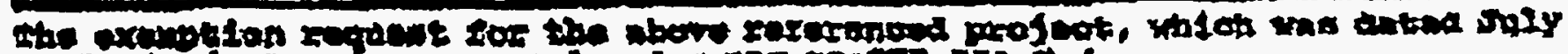

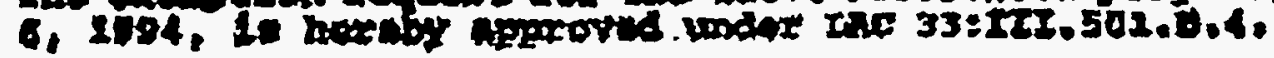

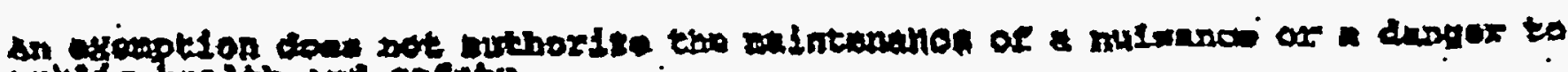
publia bunith ard andety.

- Tratora

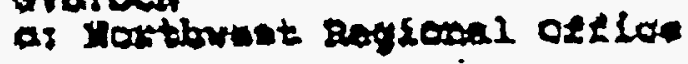

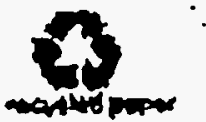

orpos oringuerr

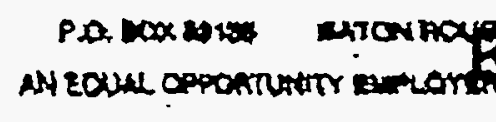

JUL 151994
Toma p.en

TOTA P. P. 
U.S. Department of Energy

Finding of No Significant Impact

Institute for Micro-manufacturing

at Louisiana Tech University

\section{AGENCY: U.S. Department of Energy}

\section{ACTION: Finding of No Significant Impact (FONSI)}

SUMMARY: The Department of Energy (DOE) has prepared an Environmental Assessment (EA) DOE/EA-0958, evaluating the construction and equipping of two components of the proposed Institute for Micro-manufacturing at Louisiana Tech University (LTU), a proposed R\&D facility to be located in Ruston, LA. and, the proposed installation of a beamline for micro-machining applications at the Center for Advanced Microstructures and Devices (CAMD) facility at Louisiana State University in Baton Rouge, LA.

The objective of the proposed project is to focus on the applied, rather than basic research emphasizing the design and development, metrology, inspection and testing, and the assembly and production of micron and submicron structures and devices. Also, the objective of the beamline at CAMD would be the fundamental study of processing and analysis technologies, including $x$-ray lithography, which are important to microstructures fabrication and electronic device development.

Based on the analysis in the EA, the DOE has determined that the proposed action does not constitute a major federal action significantly affecting the quality of the human environment within the meaning of the National Environmental Policy Act of 1969 (NEPA). Therefore, the preparation of an Environmental Impact Statement is not required.

DESCRIPTION OF THE PROPOSED ACTION:

The DOE proposes to authorize LTU to proceed with the detailed design, construction and equipping of the proposed Institute for Micro-manufacturing on the Campus of ITU, Ruston, LA. The second portion of this project would be equipment for research, studying the $x$-ray lithography micro-machining capability to be installed at the CAMD at LSU in Baton Rouge, Louisiana. These two facilities would work in parallel. House Resolution 102-177 accompanying the FY 1992 Energy and Water Appropriations Act (Pubic Law 102-104) indicated that $\$ 10$ million had been included in DOE's FY 1992 appropriation to assist the LTU with construction of the proposed Institute for Micro-manufacturing.

A total of approximately 42,000 gross square feet (gsf) would comprise the proposed Ruston campus research and development (R\&D) facility, including approximately 19,000 gsf in a single story with a clear height of 20 feet for Laboratories and clean rooms, and approximately $23,000 \mathrm{gsf}$ in a two story structure for offices, laboratories, and meeting rooms, joined to the single story structure by a two story skylight corridor. A new beam port would be installed at the CAMD in Baton Rouge, LA. The dedicated beamline of the storage ring at CAMD would be housed within the existing facility at Baton Rouge.

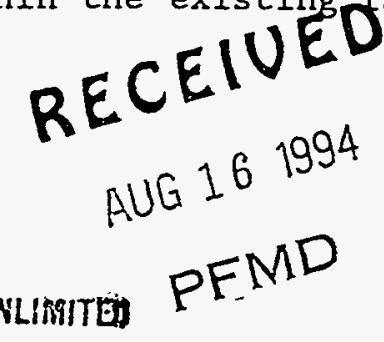




\section{ALTERNATIVES :}

The DOE considered the no action alternative. The University is committed to implementing the project without the DOE grant.

\section{ENVIRONMENTAL IMPACTS :}

The impacts of constructing, equipping and operating the proposed Institute were analyzed in the EA. Areas of potential impact evaluated in the EA included those associated with both the construction and operation of the facility.

Construction impacts evaluated included the effects on sensitive resources (historical/archeological, protected species/critical habitats, wetlands/floodplains, national forests/parks/trails, prime farmland and special sources of water); none of these categories are present at the site of the proposed facility. Also evaluated were erosion, waste disposal, air quality, noise, traffic and parking; these categories were deemed within acceptable NEPA guidelines.

Operations impacts evaluated included the effects of waste generation (domestic, sanitary, hazardous), air emissions (criteria, and air toxins), noise, socioeconomic impacts, risk of accidents, and other direct, indirect and cumulative long term impacts.

No significant environmental impacts associated with the proposed construction or operations are anticipated. This finding of no significant impact for the proposed action is based on the following factors which are supported by information and analysis in the EA.

\section{Impacts of Construction/Installation}

None of the categories of sensitive resources cited above would be affected by the project as they do not occur on or near the site. The proposed Ruston R\&D facility site is a wooded area and some trees would be removed, preserving others as part of the landscape scheme. Air quality impacts would be associated with delivery trucks and on-site construction machinery, and would be low level and transient. Noise levels would be those conventionally associated with daytime construction activities in a basement space, and are not likely to disturb residences, workers or outdoor recreation. Traffic impact would not significantly affect local circulation or parking. There would be no construction for the CAMD component.

\section{Impacts of Operations}

Waste Generation: Domestic and sanitary wastes would meet local requirements and could be readily accommodated by existing municipal services. Hazardous wastes consisting of solvents and acids would be managed in accordance with the University's existing hazardous waste management program under an existing EPA registration as a "small quantity generator" under Resource Conservation and Recovery Act.

Air Quality: Toxic air emissions, mainly from laboratory solvents, would produce insignificant levels of public exposures in relation to threshold limit values defined the American Council of Government Industrial Hygienists; this is also true for those working in the facility.

Other Effects: Noise generated indoors or outdoors would be insignificant. Socioeconomic impacts would be small in the scale of overall university economic activity. Accident risk would be very low as evidenced by zero reportable accidents involving hazardous materials at the University in the last ten years. Overall, the 
REFERENCE: DOE-EA-0958 ENVIRONMENTAL ASSESSMENT (EA) AND i. $227: \vdots$ FINDING OF NO SIGNIFICANT IMPACT (FONSI)

U. S. DEPARTMENT OF ENERGY ENVIRONMENTAL DOCUMENTS AVAILABLE ON THE INSTITUTE FOR MICROMANUFACTURING

Two documents are now available from the U.S. Department of Energy (DOE) for Public information. These documents are related to construction and equipping of two components of the Institute for Micromanufacturing (IFM) at Louisiana Tech University (LTU), in Ruston, Louisiana, and Louisiana State University (LSU) in Baton Rouge, Louisiana.

The Environmental Assessment (EA) and Finding of No Significant Impact (FONSI) documents for the building's construction and operation at LTU and an additional beamline at the Center for Advanced Microstructures and Devices at LSU were prepared by DOE. The EA documents analysis of the environmental and socio-economic impacts that might occur as a result of these actions, and characterizes potential impacts on the environment. In the EA, DOE presents its evaluation of potential impacts of construction and operation of the IFM on health and safety of both workers and the public, as well as on the external environment. Construction impacts include the effects of erosion. waste disposal, air emissions, noise, and construction traffic and parking. Operational impacts include the effects of waste generation (domestic, sanitary, hazardous), radiation exposures, air emissions (radioactive, criteria, and air toxics), noise, and new workers. No sensitive resources (wetlands, special sources of groundwater, protected species) exist in the area of project effect.

The FONSI documents DOE's determination that the proposed actions would cause no significant environmental impacts. 
incremental impacts of the project are small in relation to the ongoing impact of the University, and do not constitute significant cumulative impacts. The CAMD component would produce highly localized radiation subject to supervision of an existing radiation safety program.

\section{DETERMINATION :}

Based on the analysis in the EA, the DOE has determined that the proposed Institute for Micro-manufacturing does not constitute a major Federal Action significantly affecting the quality of the human environment within the meaning of the National Environmental Policy Act of 1969. Therefore, an Environmental Impact Statement on the Proposed Action is not required.

PUBLIC AVAILABILITY: Copies of this EA (DOE/EA-0958) are available from:

Frederick W. Wysk

Programs and Facility Management Division

U.S. Department of Energy

Chicago Operations office

9800 South Cass Avenue

Argonne, Illinois 60439

(708) $252-8618$

For further information regarding the DOE NEPA process contact:

W. Sedgefield White, NEPA Compliance officer

Environment, Safety and Health Division

Chicago Operations office

U.S. Department of Energy

9800 South Cass Avenue

Argonne, IIl. 60439

(708) 252-2101

Issued in Argonne, Illinois, this 15th day of August, 1994.

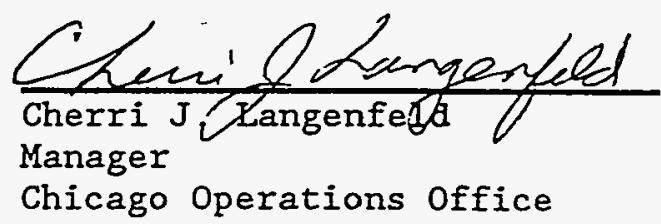


DOE, in accordance with the wish of Congress, has executed a grant with the Louisiana Tech University to partially fund the Institute for Micromanufacturing at LTU, the primary component which wil1 occupy approximately 42.000 gross square feet. This facility on the LTU campus in Ruston would be devoted to the design, development, testing, assembly, and production of micron and submicron structures and devices.

The second component, would be an additional beamline at CAMD in Baton Rouge. This component would enable LTU to perform research associated with the $x$-ray 1ithography micromachining capability at CAMD. The only construction associated with the creation of this beamline would be equipment assembly at the beam port to direct the beam to designated target areas. Funding for the project was included by Congress in DOE'S FY91 and FY92 appropriation to assist with construction of the IFM.

The EA and FONSI are available to the public for perusal at the Prescott Library at Louisiana Tech University in Ruston, Louisiana and at the DOE Chicago Operations Office reading room. Copies of the documents are also available from:

Frederick W. Wysk

U. S. Department of Energy

Chicago Operations Office

Programs and Facilities Management Division

9800 S. Cass Avenue

Argonne, IL 60439

(708) $252-8618$

Questions on the DOE NEPA process should be directed to:

Carol M. Borgstrom, Director

Office of NEPA Oversight

U. S. Department of Energy

1000 Independence Avenue, S.W.

Washington. D.C. 20585

(202) $596-4600$ or (800) $472-2756$ 